\title{
Daya Minat Penawaran Fasilitas Bioskop Masa PPKM Covid- 19 bagi Penggemar Film di Jakarta
}

\author{
Pramelani* \\ Universitas Bina Sarana Informatika; pramelani.pli@bsi.ac.id
}

Received 14 Desember 2021| Revised 7 Januari 2022 | Accepted 29 Januari 2022

*Korespondensi Penulis

\begin{abstract}
Abstrak
Pusat hiburan kembali dibuka di wilayah Jakarta dengan status Covid-19 di PPKM level 2 (dua), terutama tempat nonton bioskop offline. Dengan berbagai syarat yang berlaku selama operasi yang telah ditetapkan oleh pemerintah untuk bioskop terbuka. Protokol kesehatan harus diterapkan baik kepada pengunjung maupun staf bioskop. Selama masa pandemi ketika pemerintah menutup semua tempat hiburan termasuk bioskop offline, penggemar film beralih menonton film secara online. Bioskop pun memberikan penawaran kepada masyarakat bahwa menonton di bioskop aman selama pandemi dengan berbagai protokol kesehatan yang disediakan di dalam bioskop. Melihat hal tersebut, peneliti tertarik untuk mengetahui minat menonton bioskop offline dengan penawaran fasilitas yang ditawarkan selama masa PPKM Covid-19 bagi para penggemar film di Jakarta. Metode yang digunakan adalah metode kualitatif dengan informan yang diambil dari hasil teknik purposive sampling. Informan yang diambil dari masyarakat yang memiliki kegemaran menonton film yang berada di daerah Jakarta. Kemudian, data yang diambil dari hasil wawancara terstruktur dan menghasilkan respon yang baik dari penggemar film di Jakarta dari aspek produk film, harga dan kenyamanan yang ditawarkan bioskop. Namun sebagian besar dari mereka masih memiliki sikap protektif untuk tetap memilih nonton film online demi menjaga kesehatannya terutama dalam mengajak anak di bawah usia 12 tahun karena belum divaksin.
\end{abstract}

Kata kunci: Minat, Fasilitas; Bioskop; Film; Covid-19

\begin{abstract}
Entertainment centers have re-opened in the Jakarta area with Covid-19 status at PPKM level 2 (two), especially places to watch offline cinemas. With various conditions that apply during operations that have been set by the government for open cinema. Health protocols must be applied to both visitors and cinema staff. During the pandemic period when the government closed all entertainment venues including offline cinemas, movie fans turned to watching movies online. Cinemas also offer an offer to the public that watching in theaters is safe during the pandemic with various health protocols provided in theaters. Seeing this, researchers are interested in knowing the interest in watching offline cinemas during the Covid-19 PPKM period for film fans in Jakarta. The method used is a qualitative method with informants taken from the results of purposive sampling technique. The data were taken from interviews and resulted in a good response from film fans in Jakarta from the aspect of film products, prices and conveniences offered by cinemas. However, most of them still have a protective attitude to continue to choose to watch movies online in order to maintain their health, especially in inviting children under the age of 12 because they have not been vaccinated.
\end{abstract}

Keywords: Interests, Facilities; Cinema; Film; Covid-19 


\section{PENDAHULUAN}

Sudah hampir dua tahun, Indonesia dilanda pandemi. Pada kurun waktu pusat hiburan pernah dilakukan penutupan untuk mencegah terciptanya penularan wabah Covid-19, termasuk bioskop ditanah air. Bioskop pertama kali dibuka selama pandemi pada tanggal 23 Februari 2021 yang mampu menarik penonton sebanyak 390.400 orang. Namun, pembukaan tersebut memperhatikan protokol kesehatan dengan sistem CHSE (Cleanliness, Health, Safety, and Environmental Sustainability) dimana kapasitas penonton hanya $25 \%$, wajib masker, mencuci tangan atau menggunakan hand sanitizer, serta suhu badan tidak lebih 37,3 derajat celcius. (Kemenparekraf/Baparekraf RI, 2021)

Namun, pada saat mulai beraktivitas di luar meskipun dibatasi; masyarakat merasakan kembali untuk tidak melakukan aktivitas di luar jika tidak ada kepentingan yang sangat mendesak dan penting. Penutupan pusat hiburan pun ditutup dimana berimbas juga pada tempat nonton yakni bioskop. Pemerintah melekukan PPKM (Pemberlakuan Pembatasan Kegiatan Masyarakat) darurat karena percepatan penularan virus corona sangat meningkat dimana pada tanggal 1 Juli kasus yang terkena Covid-19 mencapai 2,2 juta sehingga pemerintah mengeluarkan kebijakan tentang PPKM darurat dimana berbeda dengan PPKM Mikro.

Selama PPKM darurat, masyarakat sebagai sarana hiburan lebih banyak menggunakan fasilitas layanan menonton film secara digital. Bioskop online menawarkan harga mulai dari Rp 5000,00 sudah dapat menikmati film kesukaan. Bioskop online dapat ditemukan pada situs Stro TV, Disney + Hotstar, Iflix, WeTV, dan Netflix. Film yang disajikan tidak hanya film lokal tetapi juga film luar negeri.(Ariefana, 2021).

Sedangkan bioskop offline baru dibuka kembali pada tanggal 16 September 2021 di beberapa daerah, termasuk Jakarta adalah bioskop CGV, Cinema XXI. Film yang ditayangkan adalah film asing yang berjudul Mogadishu, Space Jam 2, Black Widow, Fast and Furious 9, dan The Suicide Squad. (Setiawan, 2021). Harga yang ditawarkan berbeda-beda melihat lokasi menonton dimana mulai dari Rp 25.000,00 dimana tergantung juga hari tayangnya. Jika menonton pada hari Senin sampai dengan hari Kamis harga sama, namun tarif tiket lebih tinggi.pada hari Jumat maupun hari Sabtu, Minggu atau libur.

Berdasarkan instruksi Mendagri Nomor 53 Tahun 2021 tanggal 18 Oktober 2021, kota Jakarta masuk dalam kategori PPKM level 2 dimana tidak hanya umur 12- 60 tahun, melainkan anak-anak di bawah umur 12 tahun dengan didampingi orang tua sudah dapat masuk ke bioskop. Penambahan kapasitas penonton bioskop pun menjadi 70\%. Kebijakan ini berlaku dari tanggal 19 Oktober hingga 01 November 2021. (Wijaya, 2021). Melihat dari adanya peluang tersebut, Film Nussa tayang di bioskop yang merupakan film animasi buatan Indonesia dimana cocok bagi penonton kategori anak-anak.

Guna menghindari terjadinya penyebaran virus Corona, selain pembelian tiket secara online, ada beberapa peraturan yang ditujukan ke penonton yang ingin menonton bioskop offline selama PPKM level 2 yakni mendownload aplikasi PeduliLindungi sehingga dapat dilakukan screening dan pengunjung dalam status kategori hijau maupun kuning. Tidak hanya pengunjung yang melakukan persyaratan tersebut tetapi juga petugas bioskop. Area bioskop juga disesuaikan mengikuti ketentuan protokol kesehatan dari pemerintah. (Putri, 2021). Semua pengunjung dan petugas pun tetap menggunakan masker dobel untuk tetap menjaga kesehatan bersama.

Fasilitas di area bioskop disediakan hand sanitizer di setiap tempat, tersedia sabun cuci tangan di toilet, penerapan physical distancing di semua area, petugas bioskop lengkap dengan atribut masker, sarung tangan dan face shield dan selalu memberikan update materi edukasi dan informasi sesuai arahan dari pemerintah pusat dan daerah. Pengunjung bioskop tidak diperkenankan makan dan minum di dalam ruang pertunjukan bioskop, tetapi dapat makan di luar studio yakni di restoran bioskop dengan berkapasitas makan di tempat hanya 50\% dan waktu lama makan berdurasi hanya 60 menit. (Affifah, 2021) 
Melihat fenomena tersebut, penulis ingin mengetahui tentang ketertarikan menonton bioskop offline Masa PPKM Pada Penggemar Film di Jakarta dimana pemerintah telah melonggarkan kebijakan PPKM untuk ibukota negara bagi usia pengunjung yang dapat menonton bioskop offline yakni usia dibawah 12 tahun serta 12- 60 tahun. Sehingga penulis merumuskan permasalahan sebagai berikut bagaimana ketertarikan menonton bioskop offline Masa PPKM Covid-19 Pada Penggemar Film di Jakarta.

Manfaat dan tujuan yang didapat dari penelitian ini penulis bisa memberikan masukan kepada pemerintah, pemilik perfiliman, serta pelaku bisnis lainnya dalam melihat hiburan aman, nyaman dan menarik dalam masa PPKM, serta konsumen tetap terjaga kesehatan. Selain dari sisi praktis, bagi para civitas akademis dapat menjadi sorotan wawasan keilmuan dalam hal marketing di masa pandemi.

Bioskop merupakan salah satu dari pemasaran jasa di bidang entertainment. Pemasaran Jasa adalah suatu kegiatan ekonomi yang mengeluarkan produk yang bukan dikonsumsi yang berbarengan dengan waktu produksi serta terdapat nilai tambah yang diberikan berupa hiburan, kenikmatan maupun santai yang bersifat tidak berwujud.(Fatihudin \& Firmansyah, 2019). Dalam penelitian ini melihat pemasaran jasa dari segi produk, harga maupun kenyamanan. Produk yang ditawarkan adalah film-film baik dari luar negeri maupun dari Indonesia. Harga jasa berdasarkan lokasi bioskop berbeda-beda. Sedangkan kenyamanan mengacu dari kebijakan pemerintah berdasarkan aturan PPKM level 2 di daerah Jakarta.

Produk menurut Kotler dan Keller menyebutkan sebagai sesuatu yang dapat ditawarkan ke konsumen agar dapat memuaskan keinginan serta kebutuhannya. (Halim, Ardhariksa Zukhruf, Efendi, \& Sudarso, 2021). Pengertian kualitas produk merupakan produk, jasa, manusia, proses maupun lingkungan sesuai dengan yang diharapkan atau melebihi dari ekspektasi.(Rino \& Kartika, 2021)

Harga jasa adalah harga nilai jasa yang dibayarkan dengan sejumlah uang. Penentuan harga dikarenakan adanya kondisi sebagai berikut: biaya anggaran promosi, sasaran pasar yang dicapat, faktor saluran pemasaran, pandangan mengenai laba, keragaman produk jasa, faktor ada tidaknya penambahan jasa, serta faktor ancaman adanya pesaing baru. (Fatihudin \& Firmansyah, 2019)

Kenyamanan merupakan penilaian komprehensif seseorang terhadap lingkungannya dimana melibatka fisik biologis, perasaan, cahaya, suara, bau, suhu, atau hal yang lain yang dapat merangsang pikirannya. Dari tangkapan rangsangan tersebut seseorang mampu menilai apakah kondisi nyaman atau tidak. (Anita, Dja'far, \& Orinaldi, 2021)

\section{METODE}

Penelitian kualitatif digunakan dalam penelitian penulis dimana metode ini menurut Bogdan dan Taylor menyebutkan metode ini dimanfaatkan sebagai prosedur penelitian yang menghasilkan data deskriptif yang menggunakan kata-kata lebih detail. (Rukin, 2021). Kemudian dalam pengambilan teknik sampling, penulis memilih purposive sampling dimana yang menjadi informan diambil berdasarkan tujuan penelitian. Teknik ini ditegaskan pula dalam buku (Winarni, 2018) yakni teknik yang sampelnya diambil dari sumber data dengan pertimbangan tertentu. Berdasarkan topik yang dibahas peneliti mengambil informannya adalah penggemar film di Jakarta dengan menggunakan wawancara terstruktur serta didukung dari studi pustaka. Setelah dikumpulkan datanya, penulis dapat menuangkan hasil dan pembahasan yang ditemukan di lapangan sebagai analisa dari penelitian ini.

\section{HASIL DAN PEMBAHASAN}

Penulis mendapatkan informan sebanyak 20 penggemar film yang tinggal berada di daerah Jakarta baik Jakarta Utara, Jakarta Selatan, Jakarta Barat dan Jakarta Timur. Pencarian informan secara acak berdasarkan kebutuhan dari penelitian dimana mempunyai hobi menonton film. Informan berjenis kelamin 
laki-laki dan perempuan yang memiliki dominan dalam menjawab pertanyaan adalah dari kaum perempuan. Peneliti juga tidak memandang status informan maka ada yang belum menikah dan sudah menikah. Namun, persentasenya lebih besar didapatkan informan yang belum menikah. Dalam hobi menonton film, ada genre film yang disukai yakni lebih banyak menyukai film yang berjenis action meski ada penyuka romance, horror, thriller maupun komedi. Asal film yang disuka juga terlihat film barat lebih banyak dipilih selain film Indonesia, film Asia dan lainnya.

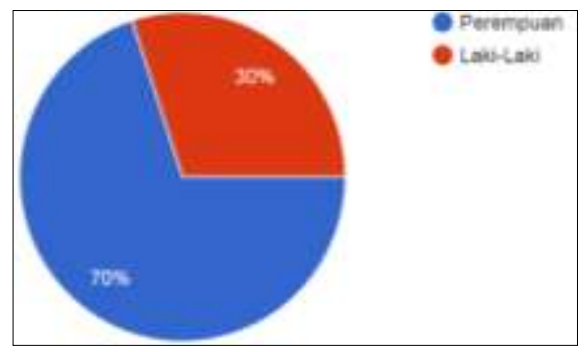

Gambar 1. Jenis Kelamin Informan (Sumber: Dokumentasi Peneliti, 2021)

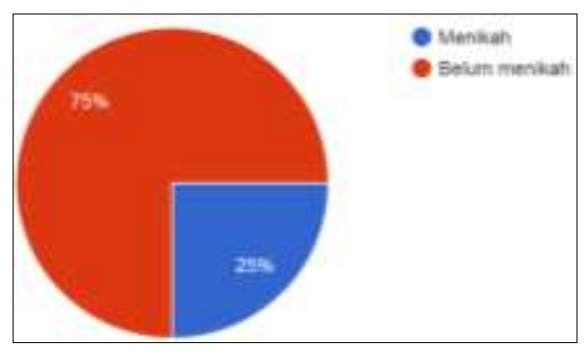

Gambar 2. Status informan

(Sumber: Dokumentasi Peneliti, 2021)

Informan dalam menonton film menggunakan media bioskop digital seperti Netflix, We TV, Viu, Stro TV, Iflix, Disney Hotstar dan Youtube. Hal tersebut sering dilakukan pada waktu bioskop offline tutup dimana mengikuti kebijakan dari pemerintah. Sedangkan, menonton film di bioskop offline lebih banyak penggemar film berkunjung ke Cinema XXI dibandingkan Blitz CGV karena harga terjangkau. Tujuan dari hobi menonton film disebutkan adalah untuk hiburan, refleshing, kebersamaan menonton bersama keluarga dan teman, mengisi waktu luang, mencari suasana yang beda dan menikmati fasilitas nyaman menonton, serta terdapat rasa penasaran dengan cerita film terbaru yang baru tayang.

Film-film yang ditayangkan di bioskop offline menurut para informan sangat bagus dan menarik dibandingkan menonton film secara online. Filmnya pun terbaru dan terupdate. Dalam bioskop offline tersedia layar besar untuk pemutaran film sehingga penonton dapat menikmati gambar film sangat jelas yang dapat memuaskan pandangan mata disertai dengan sound (suara) stereo yang sangat besar dan jernih yang menjadikan yang menonton dapat terbawa suasana cerita film. 


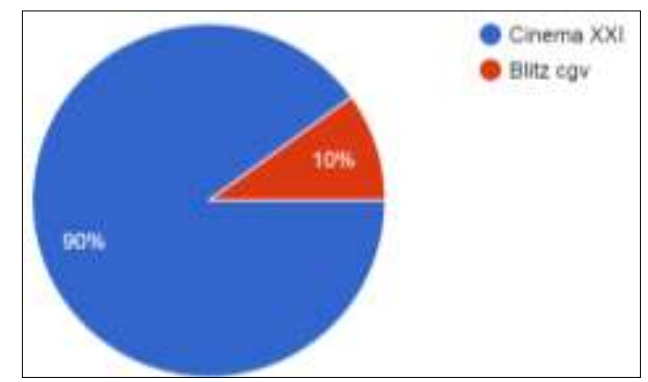

Gambar 3. Pilihan Bioskop Offline Informan (Sumber: Dokumentasi Peneliti, 2021)

Meski ada film yang ditayangkan di bioskop online, informan masih banyak yang mengakui bahwa menonton film di bioskop offline dianggap paling nyaman. Dengan fasilitas studio bioskop yang lengkap seperti layar besar, kursi yang empuk, aroma AC bioskop tidak pernah dilupakan para penonton, serta tidak perlu mengeluarkan kuota internet. Film-filmya dirilis lebih duluan di bioskop offline dengan kualitas gambar yang lebih bagus. Genre film yang disajikan juga disukai oleh informan.

Harga menonton film di bioskop offline masih dapat dijangkau oleh penonton terutama di bioskop Cinema XXI meskipun di hari weekend seperti hari Sabtu, Minggu, atau libur harga naik sedikit dikarenakan banyak yang berminat menonton dibandingkan hari biasa (weekday). Harga tiket menonton pun sangat sesuai dengan kualitas produk film dengan resolusi gambar yang bagus. Harga pun juga sesuai dengan kenyamanan dan fasilitas lainnya yang diberikan ke pengunjung karena percaya bahwa pihak bioskop melakukan penyemprotan dan membersihkan tempat duduk selama PPKM (Pemberlakuan Pembatasan Kegiatan Masyarakat) agar penonton merasa aman dan nyaman.

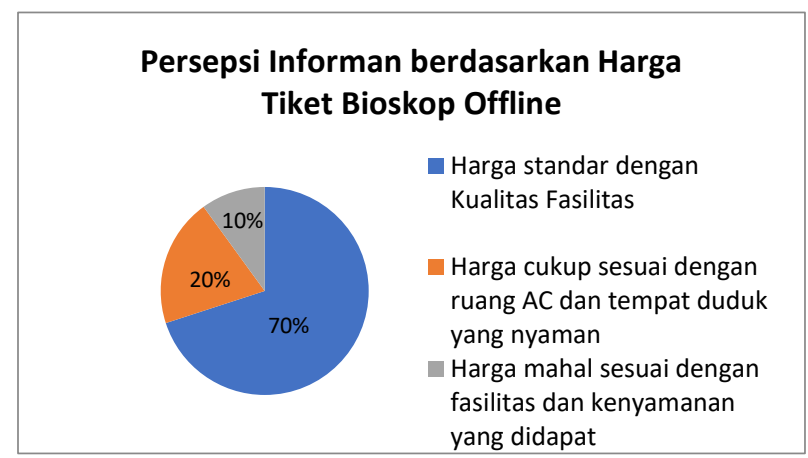

Gambar 4. Persepsi Informan Berdasarkan Harga Tiket Bioskop Offline (Sumber: Dokumentasi Peneliti, 2021)

Dengan adanya PPKM level 2, bioskop harus sesuai prosedur pemerintah yang sudah ditetapkan. Pembelian tiket nonton film secara online masih dibilang nyaman oleh penggemar film dikarenakan menghindari kerumunan agar tidak terjadi penularan Covid-19, efisien waktu dimana tidak perlu antri menunggu lama, fleksibel sehingga tinggal menunggu jam filmnya, serta lebih simpel dan praktis. Di samping itu, informan juga sadar dengan adanya aturan menonton film di bioskop berdasarkan kebijakan dari pemerintah seperti mendowload aplikasi pedulilindungi, cek suhu, maupun memakai masker. Hal itu masih dianggap nyaman 


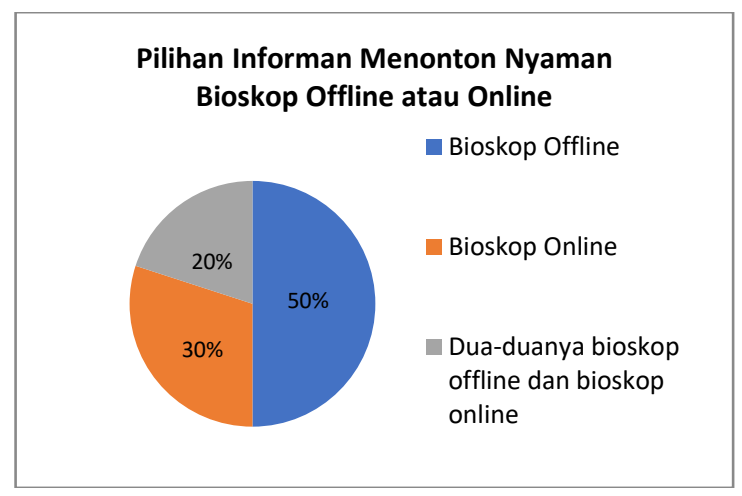

Gambar 5. Pilihan Informan Kenyamanan antara Bioskop Offline atau Online (Sumber: Dokumentasi Peneliti, 2021)

Namun, penggemar film jika menonton bioskop ada yang merasa kurang nyaman terhadap aturan menonton bioskop offline yakni tidak diperkenankan untuk makan dan minum selama pertunjukan sesuai prosedur pemerintah disebabkan diruangan studio yang dingin dimana durasi film sekitar 2 jam menjadikan perasaan bosan serta lapar dan haus bagi penonton. Meskipun dari pemerintah telah diijinkan di luar studio dimana restoran di bioskop diberi kelonggaran bagi pengunjungnya untuk dapat makan di tempat berdurasi 60 menit dengan kapasitas orang yang sudah ditentukan oleh pemerintah juga.

Ketertarikan penggemar film melihat dari penawaran bioskop offline yang diberikan ke penonton baik dalam aspek film-film yang ditayangkan, harga dan kenyamanan selama PPKM level 2 yang diterapkan pada bulan Oktober 2021 direspon baik oleh para informan. Namun, masih ada keraguan dalam diri untuk berkunjung pada masa ini dimana masih paling aman untuk menjaga kesehatan adalah tidak bepergian dulu sehingga informan lebih banyak memilih menonton film secara online dengan kondisi nonton apa adanya di rumah tanpa adanya peralatan dan perlengkapan serta nuansa yang nyaman seperti di bioskop offline. Termasuk dalam membawa anak di bawah umur 12 tahun masih belum bersedia dikarenakan belum vaksin untuk usia tersebut sehingga rawan tertular.

\section{SIMPULAN}

Kesimpulan dari Ketertarikan menonton bioskop offline Masa PPKM Covid-19 Pada Penggemar Film di Jakarta, penulis dapat melihat bahwa dari segi produk film yang ditawarkan oleh pihak bioskop sangat bagus karena selalu terbaru (update) dan dari para penggemar film banyak yang menyukai film barat. Kemudian dari aspek harga juga dinilai terjangkau berdasarkan lokasi bioskop offline yang mau ditonton dan juga sesuai dengan kualitas film yang ditawarkan serta fasilitas kenyamanan yang diberikan sehingga nuansa menonton film menjadikan ikut terhanyut ke dalam cerita film yang ditonton. Kenyamanan selama PPKM level 2 di Jakarta dengan mengikuti protokol kesehatan yang telah ditentukan oleh pemerintah, para penggemar film direspon dengan baik dimana menerima terhadap kebijakan tersebut agar tidak terjadi penularan Covid-19. Meskipun demikian, para informan banyak yang masih menimbang kembali untuk berkunjung ke bioskop offline dimana menonton secara online masih dianggap aman dan nyaman. Dalam mengajak menonton film usia di bawah 12 tahun juga masih belum bersedia untuk dibawa menonton karena pertimbangan belum divaksin Covid-19.

Implikasinya penelitian ini dapat menjadi referensi bagi mahasiswa dan civitas akademis yang lain tentang usaha perfilman atau tempat hiburan seperti bioskop yang masih masa PPKM Covid-19 khususnya dalam segi kenyamanan penonton serta fasilitas yang ditawarkan. Di samping itu, bagi para pelaku pembisnis di bidang industri perfilman digunakan untuk mengambil kebijakan yang tepat yang diterapkan demi kemajuan bisnismya yang disesuaikan dengan keadaan terkini khususnya masa pandemi. 


\section{Ucapan Terima Kasih}

Penulis mengucapkan terimakasih kepada para informan yang telah membantu memberikan pendapatnya dalam wawancara untuk mendapatkan data agar penelitian ini dapat terselesaikan dengan baik. Ucapan terimakasih juga diucapkan untuk redaksi jurnal sehingga artikel ilmiah ini dapat terbit.

\section{DAFTAR PUSTAKA}

Affifah, F. P. (2021, October). PPKM Jawa-Bali Diperpanjang hingga 1 November, Berikut Aturan Baru pada Bioskop. Tribunnews.Com. from https://www.tribunnews.com/nasional/2021/10/20/ppkm-jawa-bali-diperpanjang-hingga-1november-berikut-aturan-baru-pada-bioskop?page $=3$

Anita, Dja'far, H., \& Orinaldi, M. (2021). Pengaruh Lokasi, Fasilitas, Harga Dan Kenyamanan Terhadap Keputusan Mahasiswa Fakultas Ekonomi Dan Bisnis Islam Uin Sulthan Thaha Saifuddin Jambi Dalam Memilih Tempat Indekos. Paper Knowledge. Toward a Media History of Documents. Universitas Islam Negeri.

Ariefana, P. (2021). Daftar Streaming Nonton Film Bioskop di Ponsel Selama PPKM Darurat dan WFH. Suarabali.Id. Retrieved from https://bali.suara.com/read/2021/07/09/072500/daftar-streamingnonton-film-bioskop-di-ponsel-selama-ppkm-darurat-dan-wfh?page=all

Fatihudin, D., \& Firmansyah, A. (2019). Pemasaran Jasa (Strategi, Mengukur Kepuasan dan Loyalitas Pelanggan) (Pertama). Sleman: Deepublish.

Halim, F., Ardhariksa Zukhruf, K., Efendi, M. B., \& Sudarso, A. (2021). Manajemen Pemasaran Jasa (Pertama). Medan: Yayasan Kita Menulis.

Kemenparekraf/Baparekraf RI. (2021). Bioskop Kembali Dibuka dengan Protokol Kesehatan yang Ketat. Kemenparekraf.Go.Id. Retrieved from https://kemenparekraf.go.id/ragam-ekonomi-kreatif/BioskopKembali-Dibuka-dengan-Protokol-Kesehatan-yang-Ketat

Putri, K. (2021). Aturan PPKM Level 1-2 di Jawa dan Bali, Bioskop Dibuka untuk Anak Dibawah 12 Tahun, Ini Syaratnya. Tribun-Bali.Com. Retrieved from https://bali.tribunnews.com/2021/10/19/aturanppkm-level-1-2-di-jawa-dan-bali-bioskop-dibuka-untuk-anak-dibawah-12-tahun-ini-syaratnya

Rino, M. M., \& Kartika, L. N. (2021). Pengaruh Kualitas Produk Dan Pemasaran Digital Terhadap Keputusan Pembelian Bioskop Cinema Xxi (Studi Pada Mahasiswa Di D.I Yogyakarta). Jurnal Riset Manajemen Dan Bisnis, 16(1). Retrieved from http://ejournalfb.ukdw.ac.id/index.php/jrmb/article/view/370/352

Rukin. (2021). Metodologi Penelitian Kualitatif Edisi Revisi. (A. Rofiq, Ed.). Surabaya: CV. Jakad Media Publishing.

Setiawan, K. (2021, September). Bioskop Cinema XXI dan CGV Mulai Buka, Kenapa Tak Ada Film Indonesia? Tempo.Co. Retrieved from https://bisnis.tempo.co/read/1507449/bioskop-cinema-xxi-dancgv-mulai-buka-kenapa-tak-ada-film-indonesia/full\&view=ok

Wijaya, L. D. (2021). PPKM Level 2: Anak Boleh Masuk Bioskop di Jakarta, Kapasitas Naik Jadi 70 Persen. Teтро.Сo. Retrieved from https://metro.tempo.co/read/1518953/ppkm-level-2-anak-boleh-masukbioskop-di-jakarta-kapasitas-naik-jadi-70-persen/full\&view $=$ ok

Winarni, E. W. (2018). Teori dan Praktek Penelitian Kuantitatif Kualitatif Penelitian Tindakan Kelas (PTK) Research and Development (R\&D). (R. A. Kusumaningtyas, Ed.) (Pertama). Jakarta: Bumi Aksara. 